\title{
COMMENT
}

\section{A Paean For The Social Policy Association: A Response To Glennerster}

\section{GILBERT SMITH*}

Perhaps Howard Glennerster did not expect his note, 'A requiem for the Social Administration Association' (1988), to be taken too seriously. A response risks the danger of appearing pompous. Nevertheless, the comment makes some important points and because it has appeared in the major British journal of the discipline of Social Policy and Administration (SPA), and comes from someone who occupies a Chair in a prestigious institution of the social sciences, it does call for a reply. Without response some of the points which the note makes might well be misunderstood by those who are outside the discipline. They already have to hand ammunition enough for any destructive task, without the assistance of scholars of social policy shooting themselves in the foot.

Glennerster has reacted to the change in name of the Social Administration Association to the Social Policy Association. As the occupant of a Chair which is also entitled 'Social Administration' I have some sympathy with the feeling. (When I was appointed I deliberately did not ask my university to retitle it a Chair in Social Policy as was fashionable at the time.) Nevertheless I believe his reaction is a mistaken one. It is also depressing. The reason why several important points that are made in the note are mistaken I shall explain below. The reason why they are depressing is that their author fails to pay due credit to those exciting developments which are now taking place within SPA and which the professional association of the discipline in Britain has attempted to encapsulate in its change of title.

In summary, Glennerster makes three important points. First, he argues that Social Administration as an area of study has failed because it has not adequately examined the administrative processes of institutions as they affect service delivery. Scholars, he insists, have not researched how welfare bureaucracies actually work. In consequence they have failed consumers through their failure to make proposals about how bureaucracies could be made to work better. Second, he suggests that these failures are due to an excessive concern with theory (especially critical theory) and a neglect of the practicalities of service delivery.

\footnotetext{
* Professor of Social Administration, Department of Social Policy and Professional Studies, University of Hull.
} 
Third, he concludes that the change in the Association's titie is to be regretted because it implies that in the future even less attention will be devoted to administrative matters. Social Administrationists (if I may coin a term used by Professor Kathleen Jones) should, Glennerster admits, study social policy but they should do so only in association with administration. We should be researching social policy and social administration, he concludes.

Let us consider each of these points in turn. The first, the claim that Social Administration has not adequately devoted itself to the study of administrative matters, is perhaps the most puzzling. Surely the detailed empirical description and analysis of the everyday workings of the welfare state has been the stuff of the subject. In our teaching we insist that one of the difficulties of the discipline is the command over detail which it requires of its students. We arrange for our students to visit welfare bureaucracies and send them on placements as a part of their course. Members of Social Administration departments are themselves often heavily involved in Community Councils, Health Authorities, General Practitioner Committees and the like. And sometimes we complain that this 'service', and often local involvement, is not given the credit that it merits by colleagues in other disciplines who insist upon the virtues of pure scholarship. In research, too, the overriding feature of study after study has surely been a concern to improve the quality of service through detailed sets of administrative proposals for change. Hill and Bramley are right to observe that the subject 'reflects the practical nature of the discipline, where concerns with empirical evidence and policy development take precedence over theoretical debate' (1986, p.6).

Apart from an unusual presentation of the overall character of the discipline, Glennerster also seriously underestimates the volume of research material which has been devoted specifically to the topic of service delivery. Although I felt that I was reasonably familiar with the literature, when I recently carried out a review I was surprised at the strength of knowledge upon this topic (Smith, 1986). Indeed I concluded that such a sound foundation of material already existed on the ideologies and impacts of frontline workers, the role and impact of user perspectives on service delivery, the importance of inter-organisational relations and the impact of organisational structures upon the services, that the most useful future direction for research was not to embark upon new themes but to consolidate and add to this already substantial base.

Furthermore, Glennerster's strictures on the discipline in this respect 
are surprising since they are quite at odds with the views of the majority of recent commentators: namely, that the main thing wrong with SPA is that it has been far too concerned with administrative matters and not nearly enough concerned with the conceptual and theoretical foundations of its investigations. From Room (1979) through such varied texts as, for example, Taylor-Gooby and Dale (1981), Mishra (1984), Hindess (1987) and Lee and Raban (1988), the argument has been consistent. Social Administration's crude empiricism and excessively close alliance with the practitioner stance, has seriously inhibited the growth of the subject. Moreover an over-close alliance with the practitioner stance has in particular, and also ironically, stopped the discipline from making the most constructive of practical proposals. In a nicely penned sentence (it must surely become a 'discuss' question in some future examination paper) Glennerster says, "if we had worried less about critical theory and more about cleaning people's rubbish we would have served humanity better'. Oddly, what we now understand is that in order to improve the cleaning of people's rubbish the thing absolutely not to do is to study solely the cleaning of people's rubbish.

So why does Glennerster present the discipline thus? I doubt he is unaware of the points that I have made. They are hardly new. Perhaps it is because of the following. Undoubtedly SPA as a subject is changing very rapidly and when insecurity looms a first response is always to cling to that which we know and love. But along with much else in the life of higher education in the UK just now, the status quo is probably not an option. Additionally, the relationship between SPA and related social sciences is changing. It is characteristic of a good deal of the research on service delivery issues that it is conducted at the boundaries of SPA and related subjects such as Public Administration, Politics, Welfare Economics, Law and Sociology. Perhaps Glennerster has drawn the boundaries of SPA so tightly as, by definition, to exclude much of the material that I have in mind when I am puzzled by his failure to acknowledge it. The more constructive response here is to continue to feed avidly upon such material and use it to strengthen the distinctive core of the discipline which is now beginning to emerge.

The second main point in the 'Requiem' is the complaint that, (perhaps to summarise crudely) we have too much theory. It is true that hardly a week now passes, it seems, without the arrival of a publisher's handout advertising a new book with a title which is some variant upon the theme 'theory, welfare, policy, crisis and the future'. Nevertheless I do not find these texts a distraction from the core tasks of the discipline. The volume of material is no doubt a reaction to several decades of heavy 
empiricism, but it is, of course, a mistake to see these theoretical and empirical tasks as separate. If, as Glennerster suggests, we are 'to ask fundamental questions about the nature of bureaucratic incentives' which shape ways of life, then we should welcome the many debates now on the SPA agenda which are providing frameworks of ideas to help us pose questions of exactly this sort.

Thirdly, Glennerster insists that we should be studying social policy and administration. The mistake here is again to see these as separate activities and to draw the dichotomy. A more fruitful approach stems from the notion of 'the social policy process'. This idea directs our attention to the numerous and complex processes which accompany the movement of a general ideological statement about the nature of society, through its various stages of legislation, organisational implementation, professional action, service delivery and service outcomes through eventually to its actual and potential impact upon a clientele. The term 'social policy' is now widely regarded as encompassing this totality whereas the term 'administration' tended to confine us to the micro end of the continuum. It is true that the subject has become a broader one of late, but no less practical in its bearing for all that.

In conclusion, those of us who sense it, need to assert it: that SPA as an academic discipline is at an extremely exciting state in its development. It evidences increasing sophistication in its theory and methods. It is forging an influential position within the network of social sciences as a whole. And it continues to address major issues of the relationship between scholarship and practice in welfare in a rapidly changing society.

In spite of a difficult organisational and resource environment in higher education the Social Policy Association reflects this buoyant mood. Membership is up. Subscriptions to this Journal are up. Attendances at the annual conference are very heavy and the submission of papers to that conference reflects the volume and quality of research in the field. The change in title of the association reflects that mood.

Glennerster insists that in the end social services have lost public support not because we failed to make the equity case with sufficient conviction ... but above all because ordinary people's experiences of the services have often been demeaning and downright inefficient'. Of course there is truth in this but Malcolm Wicks makes the more important point when he says:

the failure ... to win the debate about social policy was, in large part, one of ideas, a failure to rethink policies in the face of changing social needs, and a failure to explain, to interpret and to enthuse (1987, p.11).

The italics are mine. 


\section{REFERENCES}

H. Glennerster (1988), 'A requiem for the Social Administration Association', Journal of Social Policy. $17: 1,83-84$.

M. Hill and G. Bramley (1986), Analysing Social Policy. Blackwell, Oxford.

B. Hindess (1987), Freedom, Equality and the Market, Tavistock, London.

P. Lee and C. Raban (1988), Welfare Theory and Social Policy, Sage. London.

R. Mishra (1984), The Welfare State in Crisis. Wheatsheaf, Brighton.

G. Room (1979), The Sociology of Welfare, Blackwell, Oxford.

G. Smith (1986). 'Service Delivery Issues', The Quarterly Journal of Social Affairs, 2:3, 265-283.

P. Taylor-Gooby and J. Dale (1981), Social Theory and Social Welfare, Edward Arnold, London.

M. Wicks (1987), A Future for All, Penguin, Harmondsworth. 